\title{
Studies on the Tricarboxylic Acid Cycle in Murine Leprosy Bacillus
}

\author{
Tatsuo MORI, Kayoko DOHMAE and Kenji KOHSAKA \\ (Department of Leprology, Research Institute for Microbial Diseases, Osaka University)
}

Cultivation of the leprosy bacillus and the murine leprosy bacillus is difficult and the attempt is being made for find a way to overcome this problem by clarification of the metabolic system. We have been conducting studies on the respiratory enzyme system in the murine leprosy bacillus for the past several years. It has been found that the inability of the murine leprosy bacillus to oxidize most substrates is due to the absence of the cytochrome system and lack of the electron transportsystem. In the present study, the various enzyme systems of the TCA cycle were examined at each step. It was found that in the ground extract of murine leprosy bacillus, hydratase and condensing enzyme are present in considerable amount while addition of an artificial electron acceptor is necessary for dehydrogenase and the activity of decarboxylase and the enzyme for oxidative decarboxylation are very weak.

As may be seen in Fig. 2, the murine leprosy bacillus possesses fumarate hydratase (fumarase) activity and forms radio active malic acid from radio active fumaric acid. As no cytochromes are present in the crude extract, malic dehydrogenase is unable to act and malic acid accumulates.

Fig. 3, shows that the murine leprosy bacillus has succinic dehydrogenase activity and produces radio active fumaric acid and malic acid from radio active succinate. Auto-oxidisable phenazine methosulfate was added as an electron transpost system of succinic dehydrogenase. This dye, at the same time, becomes an electron acceptor for the malic dehydrogenase system but as the decarboxylation of pyruvate are inhibited, condensing enzyme is not able to act and as a result malic acid and fumaric acid accumulate.

As may be seen in Table 2 and 3, the murine leprosy bacillus has citrate synthase (condensing enzyme) activity but citrate is not formed from the oxaloacetate alone or oxaloacetate plus pyruvate systems. This suggests that the formation of acetyl CoA from oxaloacetate and pyruvate is inhibited in the cell free system.

The aconitate hydratase (aconitase) activity of the murine leprosy bacillus is quite strong as shown in Table 2 and citrats is formed from cis-aconitate and isocitrate.

Quantitative determination of the dehydrogenase activity of crude extract using triphenyl tetrazolium chloride as the electron acceptor gives the results indicated in Table 1. and a characteristic finding is apparent. With oxaloacetate as the substrate, formation of formazan, equivalent to the substrate used, is not observed. Oxalosuccinate, which is said to be spontaneously decarboxylated by animal tissue, is utilized with difficulty by the murine leprosy bacillus and formation of $\alpha$-ketoglutarate appears to be difficult. 
Examination of the quantitative relationship of the formazan which is formed to the substrate shows that with citrate, cis-aconitate or iso-citrate as substrate, the formation is strongest with citrate followed in descending order by cis-aconitate and isocitrate.

The dehydrogenase step in the TCA cycle is the state of iso-citrate dehydrogenase so the order of formazan formation should be iso-citrate, cis-aconitate, citrate. On the other hand, formazan is not formed when only oxaloacetate is used so that malic acid is not formed by reverse action of condensing enzyme.

As inactivation of some enzyme system may take place at the stage of preparation of the ground extract of the murine leprosy bacillus a definite conclusion cannot be made regarding the metabolic system of the live organism on the basis of the present study alone but the findings suggest the presence of a metabolic system for citrate which does not pass through the TCA cycle. When $\alpha$-ketoglutarate is used as the substrate fomrazan formation is observed but succinate is not formed and as shown is Fig. 4, almost all of the substrate is converted to glutamic acid.

Isocitrate lyase (isocitritase) activity is said to be strong when the organism is cultivated under anerobic conditions and a study was carried out in an attempt to verify this but is may be seen in Table 4, marked glyoxylate formation was not found.

It has been reported that succinic semialdehyde is formed, as a kind of amino acid fermentation, by a transamination reaction between $\gamma$-amino butyric acid, which is produced by glutamic acid decarboxylase, and $\alpha$-ketoglutaric acid and succinic acid is then formed from the succinic semialdehyde.

When radio active glutamic acid is added to the crude extract of murine leprosy bacillus, however, neither $\gamma$-amino butyric acid nor succinic acid could be detected.

In studying the TCA cycle system in the murine leprosy bacillus, it must be considered that the enzyme systems may be as well as inactivated at the stage of extraction, and studied their activities related to the terminal electron transport systems. There are many unknown factors but from the standpoint of cultivation of the murine leprosy bacillus, it is believed that the clarification of the terminal electron transport system is more important than the problem of what carbon source to use in the culture. medium.

(This investigation was partially supported by a grant from the World Health Organization.) 


\section{鼠顆菌における Tricarboxylic Acid Cycle}

\section{の酵素系について}

森竜男, 堂前嘉代子, 高坂健二

大阪大学微生物病研究所, 癩部門

（受付 1966年 9 月20日）

\section{緒言}

瀬菌, 鼠癩菌の培養が甚だ困難であることから，鼠癩 菌の代謝系をしらべて培養への手がかりを得ようと, 我 々は数年来鼠癩菌の呼吸酵素系についてしらべてきた。 Gray 等1) は数十種の基質を用い，ワールブルグ検圧法に より鼠癩菌の酸素消費を测定し，いずれの基質も鼠癩菌 の酸素消費を増加せしめなかったと報告している。伊藤・ 園田 ${ }^{2)}$ はそれを追試するとともに鼠癩菌の酸素消費を増 加せしめる因子の研究を行った。森等 3 はむし鼠瀬菌が 特別に利用しうる炭素源があるとするならば，それらの 炭素源か酸化されるためには，何らかの電子伝達系を経

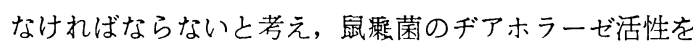
検討した。その結果, 還元助酵素 1・トリフエニール・テ トラゾリウムクロライド還元酵素活性を認めたが，電子 受容体として人工色素を用いない場合，自然の状態での 電子伝達系が, 無細胞抽出液の段階では完全に中断され ていることを見出した。日下等) は鼠癩菌のチトクロー ム系を詳細に検討して，鼠癩菌にはチトクローム系が全 然見出されないてとを明らかにした。かくして Gray 等 によって始められた鼠癩菌の基質酸化能の欠損は，チト クロームの欠損にもとづく電子伝達系に由来したもので あり, 鼠瀬菌が特別に利用しうる炭素源が存在するので はないととがわかった。

今回は鼠瀬菌のチトクローム系の欠損を人工色素で補 ってやる方法を用い, Tricarboxylic Acid Cycle (TCA サイクル）系の諸酵素活性について検詩した。

\section{実 験 方 法}

鼠癩菌の集菌法: C $3 \mathrm{H}$ ○ $\times \mathrm{dd} 0$ \& の交配 $\mathrm{F}_{1}$ マウス の胸部皮下に鼠瀬肉芽腫の 1000 倍乳液 $0.2 \mathrm{ml}$ を注射し, 4〜5ケ月後にできた鼠癩肉芽腫を原料とした。このマウ スにでる鼠癩肉芽腫は結合組織が少く, 菌の収量が非常
によいので，森56) の方法を簡略にした Fig. 1 の方法 によって集菌した。

鼠癩菌磨砕抽出液作成法 : 凍結乾燥した鼠瀬菌を科量 し，冷却した乳鉢にて同重量のガラス粉とともに磨砕 し, 少量の緩衝液にて菌をペースト状にして約60分間磨 砕した。緩衝液にて抽出後 $8000 \mathrm{rpm} に て$ 遠沈し, 生 菌を除き，その上清を粗酵素液として用いた。

ペーパークロマトグラフィーの試料の調製法 : 反応液 を Visking の透析用セロフアン袋に入れて，少量の蒸 溜水に対して氷室中で透析し，外液を 12 時間毎に 3 回 交換し，その透析外液を集めて凍結乾燥した。残楂を $0.5 \mathrm{ml}$ の蒸溜水にとかして，その $0.1 \mathrm{ml}$ をペーパーク ロマトグラフィー用に用いた。

ペーパークロマトグラフィー：有機酸はブタノール： 蟻酸 : 水 $=10: 2: 5$ の溶媒で上昇法展開した後, 室温に 4 日放置して十分に蟻酸を除き， $0.1 \%$ のブロモクレゾ ール・グリーンのアルコール溶液を噴霧した。なお沪紙 全体が黄色で有機酸のスポットの判定に困難な場合に は, アンモニヤの微量に存在する部屋にて, 沪紙がグリ ーンになるのを待って黄色のスポットを判定した。

アミノ酸は水飽和フエノールの溶媒で上昇法展開した 後, 室温乾燥して $0.1 \%$ ニンヒドリンの水飽和ブタノ一 ル溶液を噴蓩し, $110^{\circ} \mathrm{C} 10$ 分加熱の後にアミノ酸のスポ ットを判定した。

アクチグラフ：ペーパークロマトグラフにて展開し た放射性化合物を発色せしめ, アクチグラフ (Nuclear Chicago Co.) にて放射性化合物の counts を自記せし め, 合成品 spot と対比した。

酵素活性の測定法 : 脱水素反応はトリフエニール・テ トラゾリウム・クロライドを電子受容体とし, ツーンベ ルグ管にて嫌気的に行い, 生成されたフオルマザンの赤 色を醋酸エチルにて抽出し，480 $\mathrm{m} \mu$ にて比色定量した。 フマレート・ハイドラテースはフマール酸からリンゴ酸 
Fig. 1. Collection Method of Murine Leporsy Bacillus

Murine leproma $9.7 \mathrm{~g}$ (dry weights $2.25 \mathrm{~g}$ ) were minced with scissors, homogenized for 2 minutes with $10 \mathrm{ml}$ distilled water in Waring blender, added $35 \mathrm{ml}$ of distilled water.

centrifugation for $8:$ minutes at $600 \times \mathrm{g}$

sup.

taken up with pipette

filter through gauze

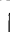

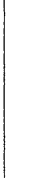

homogenizd for a minute in Waring
prep.
blender, added $35 \mathrm{ml}$ of distilled water
centrifugation for 8 minutes at $600 \times \mathrm{g}$

suspened in $10 \mathrm{ml}$ of distilled water,

homogenized for 30 seconds in waring

blender, added $40 \mathrm{ml}$ of distilled water

centrifugation for 15 minutes at $900 \times \mathrm{g}$

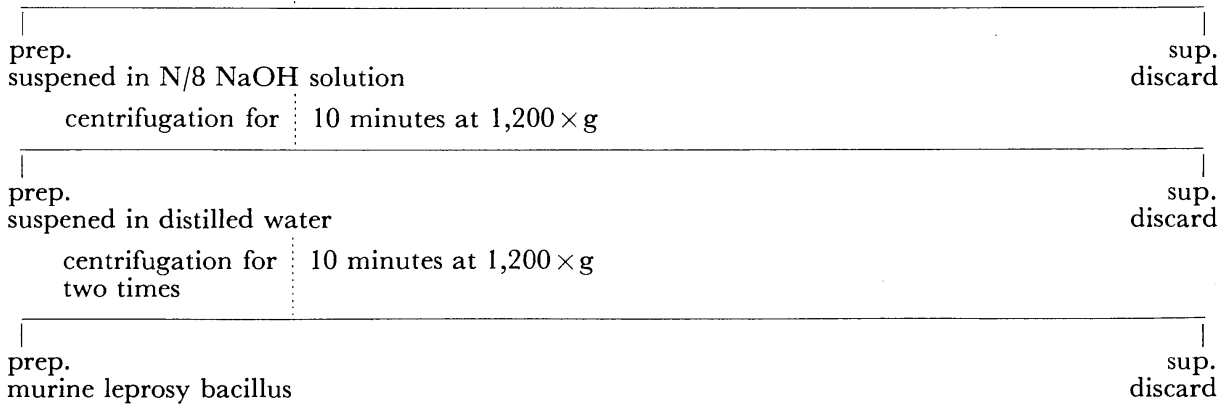

(weights of the lyophylization bacilli were $120 \mathrm{mg}$, yield $5.3 \%$ )

の形成をペーパークロマトグラフィーにて検討した。コ ハク酸脱水素活性はフエナジンメトサルフェイトを自動 酸化還元系として加え，コハク酸からフマール酸および リンゴ酸の形成を，ペーパークロマトグラフィーにて検 討した。アコニテート・ハイドラテースアコニターゼは シス・アコニット酸および DL-イソクエン酸からクエ ン酸の形成を, サイトレート・ジンテース（縮合酵素） はオキザロ醋酸とアセチル CoA からクエン酸の形成を みた。イソサイトレート・リアーゼ（イソサイトリテー ス）は DL-イソクエン酸からグリオキシル酸の形成を みた。

化学的定量法：クエン酸は Natelson ${ }^{7)}$ の方法, グリオ キジル酸は Friedmann \& Haugen ${ }^{8)}$ の直接法によった。

材料 : $1,4{ }^{14} \mathrm{C}$ フマール酸 ; specific activity $4.94 \mathrm{mc} /$ $\mathrm{mM}, 2,3{ }^{14} \mathrm{C}$ コハク酸; specific activity $4.0 \mathrm{mc} / \mathrm{mM}$, $5{ }^{14} \mathrm{C} \alpha$-ケトグルタル酸 ; specific activity $9.33 \mathrm{mc} / \mathrm{mM}$
は日本放射性同位原素協会のものを第一化学薬品KKか ら，オキザロ醋酸, グリセルアルデヒド 3 燐酸は Nutri tional Biochemicals Co. より, シス・アコニット酸は Mann Research Laboratories Inc. より, DL-イソ・ク エン酸, CoA, アセチル CoA, ピリドキサル $5^{\prime}$ 燐酸, 助 酵素 I (NAD), 助酵素II (NADP), フエナジン・メト サルフエイト (PMS) は Sigma Chemical Co. より, リポ酸, チアミンピロ燐酸, オキザロコハク酸は東京化 成工業KKにより， $\alpha$-ケトグルタル酸は協和醴酵工業 $\mathrm{KK}$ より,グルコーズ 6 燐酸, フマール酸, コハク酸は和光 純薬KKより，グリオキシル酸は Maruwaka 化学, DLリンゴ酸は石津化学工業KKより夫々購入し, 他の試薬は 市販の特級品を用いた。

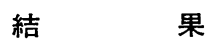

フマレート・ハイドラテース：フマール酸に水が附加 
されてリンゴ酸ができるフマレート・ハイドラテース （フマラーゼとも云う）活性をみるために， $1,4{ }^{14} \mathrm{C}$ フ マール酸を基質に用い，放射性リンゴ酸の形成をぺーパ 一クロマトグラフにて観察した。Fig. 2 に示すように著 明なリンゴ酸の形成がみられた。フマール酸とリンゴ酸 の放射活性の割合から，乙の反応はリンゴ酸形成の方向 にかたよっていると考えられる。

コハク酸脱水素酵素：鼠癩菌にはチトクローム系が欠 損しているので，コハク酸脱水素酵素につながる電子伝 達系として, 自動酸化性のフエナジンメトサルフエイ ト9) を加えて, 時々振盪しながら好気的に反応を行わせ た。基質として $2,3{ }^{14} \mathrm{C}$ コハク酸を用い，放射性反応生 成物をペーパークロマトグラフィーにて検討した。Fig. 3 にみられるように放射性のフマール酸とリンゴ酸の形 成がみられた。コハク酸脱水素酵素により形成されたフ マール酸から，同時に存在しているフマレート・ハイド ラテースによってリンゴ酸が形成されたものである。

TCA サイクル系の基質を用いてのフオルモザン形成 能: TCA サイクル系で脱水素反応の過程はイソクエン 酸脱水素酵素, $\alpha$-ケトグルタル酸脱水素酵素, コハク酸 脱水素酵素，リンゴ酸脱水素酵素および焦性ブドウ酸脱 水素酵素の 5 力所である。TCA サイクル系の基質を用 い鼠癩菌の磨砕抽出液により形成されるフォルマザンの

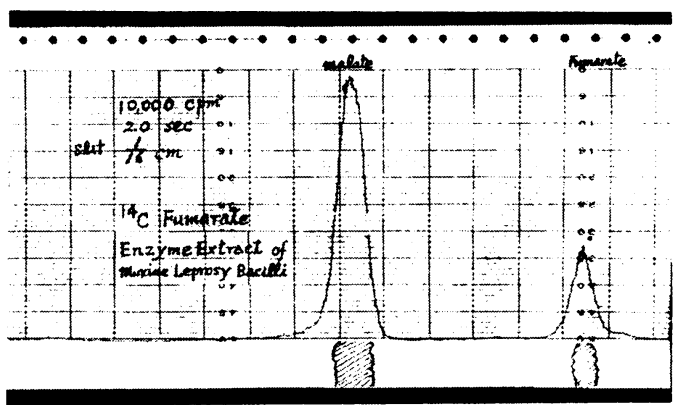

Fig. 2. Fumarate Hydratase Activity of Murine Leprosy Bacillus : Formation of Radio Active Malic Acid from Radio Active Fumaric Acid

$0.06 \mathrm{mc}$ of $1,4^{14} \mathrm{C} \cdot$ maric acid, specific activity $4.94 \mathrm{mc} / \mathrm{mM}$ was used as substrate without adding carrier cold fumarate. $0.2 \mathrm{~g}$ of lyophylized murine leprosy bacilli (Hawaiian Strain) were ground with $2 \mathrm{ml}$ of phosphate buffer $\mathrm{M} / 100, \mathrm{pH} 7.0$. The supernatant was used as enzyme solution. Incubation was carried out in $37^{\circ} \mathrm{C}$ for 300 minutes under anaerobic condition. Paper-chromatography: reaction material was developed with butanol: formic acid:water $=10: 2: 5$ by ascending method.
量を定量した成績が Table 1 である。焦性ブドウ酸は 酸化的脱炭酸によりアセチル CoA になるととあに脱水 素反応が組合さっているのであるが10), 殁ど活性がみら れない。リンゴ酸は最も活性が強く, リンゴ酸脱水素活 性とビタミン $\mathrm{K}$ を経るリンゴ酸酸化酵素活性 ${ }^{11}$ （この酵 素活性については別の機会に報告する）の総和として表 わされている。オギザロ醋酸は脱炭酸 $\left.{ }^{12}\right)$ れて焦性ブド ウ酸となってから，あるいはアセチル CoA と縮合して クエン酸となってから，または酸化的脱炭酸として直 接 ${ }^{13)}$ 脱水素されるわけであるが，フオルマザンの形成は 対照と差がない。コハク酸はやや活性がみられるが用い た TTC がコハク酸脱水素酵素に直接に接続した電子受 容体でないためか，それ程強い活性を示さない。

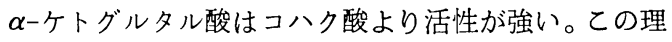
由として， $\alpha$-ケトグルタル酸脱水素酵素とコハク酸脱水 素酵素の両方の総和がでているのか, 他の系に流れてか ら基質として作用しているためなのかあきらかでない。 オギザロコハク酸は脱炭酸されて $\alpha$-ケトグルタール酸 になってから脱水素酵素の段階に入るのであるが14)， フ オルマザンの形成が対照と差がないことから，オキザロ コハク酸の脱炭酸は行なわれないのではないかと考えら

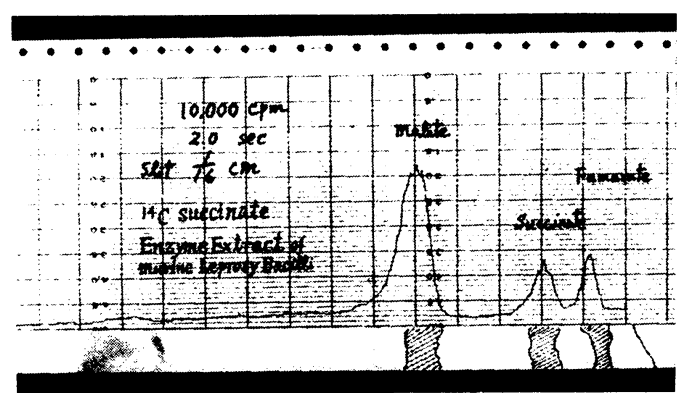

Fig. 3. Succinic Dehydrogenase Acitivity of Murine Leprosy Bacillus : Formation of Radio Active Fumaric and Malic Acids from Radio Active Succinic Acid

$0.05 \mathrm{mc}$ of $2,3^{14} \mathrm{C}$ succinic acid, specific activity 4.0 $\mathrm{mc} / \mathrm{mM}$ was used as substrate without adding carrier cold succinate. Murine leprosy bacilli (dry weights $1.4 \mathrm{~g}$ ) were suspended in $20 \mathrm{ml}$ of phosphate buffer $\mathrm{M} / 100$, $\mathrm{pH} 7.0$, and disintegrated by French press under 500 atmospheric pressures. $2 \mathrm{ml}$ of the disintegrated cell suspension was used as enzyme. $2 \mathrm{mg}$ of phenazine methosulfate was used as electron catalyzer. Incubation was carried out in $37^{\circ} \mathrm{C}$ for 300 minutes occasionally shaking under aerobic condition. Paper-chromatography: reaction material was develpoped with butanol: formic acid: water $=10: 2: 5$ by ascending method. 
Table 1. Dehydrogenase Activities of Murine Leprosy Bacillus

\begin{tabular}{l|c}
\hline \multicolumn{1}{c|}{ substrates } & $\begin{array}{c}\text { formazan formed } \\
\times 10^{-7} \mathrm{~mol}\end{array}$ \\
\hline pyruvate & 4.9 \\
malate & 4.8 \\
* oxaloacetate & 5.0 \\
succinate & 14.8 \\
* $\alpha$-ketoglutarate & 4.8 \\
$*$ oxalosuccinate & 6.5 \\
isocitrate & 8.4 \\
cis-aconitate & 4.8 \\
citrate & 7.0 \\
$*$ pyruvate+oxaloacetate & 10.0 \\
lactate & 11.0 \\
glucose & 4.9 \\
glucose-6-p & 6.5 \\
glyceraldehyde-3-p & 4.7 \\
\hline
\end{tabular}

$0.5 \mathrm{~g}$ of lyophylized murine leprosy bacilli (Hawaiian Strain) were ground with glass powder and extracted with $20 \mathrm{ml}$ of phosphate buffer $\mathrm{M} / 20, \mathrm{pH}$ 7.0 contained $4 \times 10^{-6} \mathrm{~mol} / \mathrm{ml}$ cysteine. The supernatant was used as the enzyme solution. 1.0 $\mathrm{ml}$ enzyme solution, $0.1 \mathrm{ml}$ NAD $2 \times 10^{-7} \mathrm{~mol}, 0.5$ $\mathrm{ml} \mathrm{H}_{2} \mathrm{O}$ in main vessels, $0.2 \mathrm{ml}$ substrate $2 \times 10^{-5}$ mol, $0.2 \mathrm{ml}$ TTC $10^{-5} \mathrm{~mol}$ in each side vessel. Incubation was carried out at $37^{\circ} \mathrm{C}$ for 150 minutes under anaerobic condition.

${ }^{*} \mathrm{MgCl}_{2} \quad 10^{-6} \mathrm{~mol}$, lipoic acid $2 \times 10^{-7} \mathrm{~mol}$, TPP $2 \times 10^{-7} \mathrm{~mol}$ and Co A $2 \times 10^{-7} \mathrm{~mol}$ were added.

る。あるいはイソクエン酸から酸化的脱炭酸により一挙 に $\alpha$-ケトグルタル酸ができるために，中間代謝産物の オキザロコハク酸を経ないのかあ知れない。イソクエン 酸，シス・アコニット酸およびクエン酸は TCA サイク ル系に従えばイソクエン酸の段階で脱水素されるのであ るが, フオルマザンの形成量をみると, クエン酸, シス・ アコニット酸およびイソクエン酸の順になっており，イ ソクエン酸脱水素酵素によるフオルマザンの形成とは考 えにくい。むしろイソクエン酸はシス・アコニット酸か らクエン酸を経て脱水素されていると考えるべきであろ う。クエン酸からどのような経路で脱水素過程に入るか はわからないが, サイトレート・ジンテースの逆回転に よりリンゴ酸ができてから脱水素されると仮定すれば, オキザロ醋酸が基質にならない矛盾がある。焦性ブドウ 酸とオキザロ醋酸を加えた系では，クエン酸ができてか
ら脱水素されるわけであるが，対照と殆ど差がない。焦 性ブドウ酸を用いたのではサイトレート・ジンテース活 性がみられない。醗酵系, Hexose-Pentose 回路との関 連を知るために，乳酸，グルコーズ，グルコーズ 6 燐 酸，グリセルアルデヒド 3 燐酸を追加したが，醗酵系の 酵素は殆ど活性がなく，グルコースも燐酸化したものを 与えないと活性がみられないことから，粗抽出液ではグ ルコースの燐酸化能が阻害されていると考えられる。

アコニテート・ハイドラテース（アコニテース）: シ ス・アコニット酸とイソ・クエン酸からクエン酸の形成 をみた。Table 2 にみられるように，どちらの基質から もクエン酸の形成がみられた。

サイトレート・ジンテース (縮合酵素) : Table 3 に みられるように，才キザロ醋酸とアセチル CoA からは 㠑明なクエン酸の形成があるが，アセチル CoA の代り に焦性ブドウ酸を用いたものでは殆どクエン酸の形成が みられない。オキザロ醁酸のみの場合も同様である。山 村, 楠瀬等 ${ }^{15)}$ が鳥型菌竹尾株の粗抽出液でサイトレー ト・ジンテース活性をみている成績では，オギザロ醋酸 のみにて著明にクエン酸の形成がみられているが，鼠癩

Table 2. Aconitate Hydratase Activity of Murine Leprosy Bacillus

\begin{tabular}{c|c}
\hline substrate & $\begin{array}{c}\text { citrate formed } \\
\times 10^{-6} \mathrm{~mol}\end{array}$ \\
\hline- & 0 \\
cis-aconitate $4 \times 10^{-5} \mathrm{~mol}$ & 16.0 \\
DL isocitrate $8 \times 10^{-5} \mathrm{~mol}$ & 4.0 \\
\hline
\end{tabular}

$0.5 \mathrm{~g}$ of lyophylized murine leprosy bacilli (Hawaiian Strain) were ground with glass powder, and the enzyme was extracted with $10 \mathrm{ml}$ of tris buffer $\mathrm{M}$ / 20, $\mathrm{pH}$ 7.6. The supernatant was used as the enzyme solution. $2 \mathrm{ml}$ of enzyme and $0.5 \mathrm{ml}$ of substrate were incubated for 300 minutes at $37^{\circ} \mathrm{C}$ under anaerobic condition.

\begin{tabular}{c|c}
\hline \hline substrate & $\begin{array}{c}\text { citrate formed } \\
\times 10^{-6} \mathrm{~mol}\end{array}$ \\
\hline- & 0 \\
cis-aconitate $4 \times 10^{-5} \mathrm{~mol}$ & 9.9 \\
DL isocitrate $8 \times 10^{-5} \mathrm{~mol}$ & 3.0 \\
\hline
\end{tabular}

$0.6 \mathrm{~g}$ of lyophylized murine leprosy bacilli (Hawaiian Strain) were ground, and extracted with $20 \mathrm{ml}$ of tris buffer $\mathrm{M} / 20$, $\mathrm{pH} 7.0$. Incubation times were 150 minutes. The other conditions were same above, 
Table 3. Citrate Synthase (Condensing Enzyme) Activity of Murine Leprosy Bacillus

\begin{tabular}{c|c|c|c|c}
$\begin{array}{c}\text { crude extract } \\
1.3 \mathrm{ml}\end{array}$ & $\begin{array}{c}\text { oxaloacetate } \\
10^{-5} \mathrm{~mol} \\
0.3 \mathrm{ml}\end{array}$ & $\begin{array}{c}\text { acetyl CoA } \\
6 \times 10^{-6} \mathrm{~mol} \\
0.4 \mathrm{ml}\end{array}$ & $\begin{array}{c}\text { pyruvate } \\
10^{-5} \mathrm{~mol} \\
0.4 \mathrm{ml}\end{array}$ & $\begin{array}{c}\text { citric acid } \\
\text { formed } \\
\times 10^{-7} \mathrm{~mol}\end{array}$ \\
\hline+ & - & - & - & -1.0 \\
+ & + & - & - & 0 \\
+ & - & + & - & 1.0 \\
+ & + & - & + & 1.1 \\
+ & + & + & - & 22.0 \\
\hline
\end{tabular}

$0.4 \mathrm{~g}$ of lyophylized murine leprosy bacilli (Hawaiian Strain) were ground with glass powder, and the enzyme was extracted with $6.0 \mathrm{ml}$ of phosphate buffer $\mathrm{M} / 10$, $\mathrm{pH}$ 7.4. The supernatant was used as the enzyme solution. Total volume make to two $\mathrm{ml}$ with distilled water, and incubation was cairied out at $37^{\circ} \mathrm{C}$. for 240 minutes under aerobic condition.

Table 4. Isocitrate Lyase (Isocitritase) Activity of Murine Liprosy Bacillus

\begin{tabular}{c|c|c|c}
$\begin{array}{c}\text { crude extract } \\
1 \mathrm{~m}^{1}\end{array}$ & $\begin{array}{c}\mathrm{As}_{2} \mathrm{O}_{3} 0.5 \mathrm{ml} \\
10^{-5} \mathrm{~mol}\end{array}$ & substrate $0.5 \mathrm{ml}$ & $\begin{array}{c}\text { optical density } \\
\text { at } 540 \mathrm{~m} \mu\end{array}$ \\
\hline+ & - & - & 0.25 \\
+ & - & DI. isocitrate $8 \times 10^{-5} \mathrm{~mol}$ & 0.31 \\
+ & - & cis-aconitate $4 \times 10^{-5} \mathrm{~mol}$ & 0.32 \\
+ & + & - & 0.22 \\
+ & + & DL socitrate $8 \times 10^{-5} \mathrm{~mol}$ & 0.29 \\
- & - & glyoxylate $5 \times 10^{-7} \mathrm{~mol}$ & 0.44 \\
- & -- & glyoxylate $10^{-6} \mathrm{~mol}$ & 0.74 \\
- & - & glyoxylate $2 \times 10^{-6} \mathrm{~mol}$ & 1.00 \\
\hline
\end{tabular}

$0.5 \mathrm{~g}$ of lyophylized murine leprosv bacilli (Hawaiian Strain) were ground with glass powder, and the enzyme was extracted with $10 \mathrm{ml}$ of tris buffer $\mathrm{M} / 20$, pH 7.6. The supernatant was used as the enzyme solution. Reaction mixture make to $2 \mathrm{ml}$ with distilled water, and was incubated for 300 minutes at $37^{\circ} \mathrm{C}$ under anaerobic condition. The reaction mixtures were treated with $0.4 \mathrm{ml}$ of $10 \% \mathrm{TCA}$, and $1.6 \mathrm{ml}$ of distilled water and $1 \mathrm{ml} 2,4$ dinitrophenyl hydrazine $2 \mathrm{~N} \mathrm{HCl}$ solution were added to the deproteinized supernatants. After 3 minutes, $3 \mathrm{ml}$ of $1.5 \mathrm{~N} \mathrm{NaOH}$ solution was added to each tube, and make to $10 \mathrm{ml}$ with distilled water.

䒩の埸合には菌磨砕抽惟の段階で，オキザロ醋酸脱炭酸 酵素活性および焦性ブドウ酸からのアセチル CoA 形成 酵素が失活したのかも知れない。あるいは鼠癩菌には酸 化的脱炭酸酵素活性が弱く, 他の代謝系からアセチル $\mathrm{CoA}$ が供給されるのかも知れない。

イソサイトレート・リアーゼ（インサイトリター ゼ：㨀気的に増殖した菌でイソクエン酸をコハク酸之 グリオキシル酸に分解する酵素活性の強いことが報告さ れている ${ }^{16)}$ 。鼠癩菌では Table 4 亿みられるように著 明なグリオキジル酸の形成はみとめられない。 $\alpha$-ケトグルタル酸脱水素酵素: $\alpha$-ケトグルタール酸 を基質にした場合フオルマザンの形成がかなりみられた ので, $5,{ }^{14} \mathrm{C} \alpha$-ケトグルタール酸を基質に用い, 反応生 成物をペーパークロマトグラフィーにて検執した。Fig. 4, 5 にみられるようにコハク酸, リンゴ酸の形成はみら れず，殆どすべての放射性 $\alpha$ ケトグルタル酸はグルタミ ン酸になっていた。用いた醏素が粗酵素であったため， どてからかアミノ基か筫入されたもの上考えられる。 グルタミン酸脱炭酸酵素: $\alpha$-ケトグルタル酸がグルタ ミン酸になり，グルタミン睃脱炭踆酵素により $r$ ーアミ 
Table 5. Glutamic Decarboxylase Activity of Murine Leprosy Bacillus

\begin{tabular}{l|c|c|c}
\hline \multicolumn{1}{c|}{ enzyme $1 \mathrm{ml}$} & $\begin{array}{c}\text { acetate buffer } \\
\mathrm{M} / 20, \mathrm{pH} 4.8\end{array}$ & substrate & $\begin{array}{c}\text { formed } r \text {-amino } \\
\text { butyric acid }\end{array}$ \\
\hline crude extract & $1 \mathrm{ml}$ & - & - \\
crude extract & $1 \mathrm{ml}$ & glutamate $10^{-5} \mathrm{~mol}$ & - \\
crude extract & $1 \mathrm{ml}$ & *radio active glutamate & - \\
crude extract + cell debris & $1 \mathrm{ml}$ & glutamate $10^{-5} \mathrm{~mol}$ & - \\
\hline
\end{tabular}

* reaction product of Fig. 4.

$0.4 \mathrm{~g}$ of lyophylized murine leprosy bacilli (Hawaiian Strain) were ground with glass powder, and the enzyme was extracted with $5 \mathrm{ml}$ of distilled water. The supernatant and cell debris were used as enzyme. Pyridoxal-5-p $10^{-7} \mathrm{~mol}$ was added to each tube, $3 \mathrm{ml}$ of reaction mixture was incubated for 300 minutes at $37^{\circ} \mathrm{C}$ under anaerobic condition. The formation of $r$ amino butyric acid was observed as a ninhydrin positive spot or radio active peak on the paper-chromatography, developed with water saturated phenol.

ノ酪酸ができ, $r$-アミノ酪酸と $\alpha$-ケトグルタル酸との トランスアミネーションによりサクシニック・セミアル デヒドが形成され，乙れの酸化によりコハク酸ができる

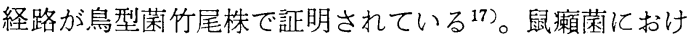
るケトグルタール酸からのコハク酸形成反応をみるため に，グルタミン酸脱炭酸酵素を検討したが， Table 5 に みられるように rーアミノ酪酸の形成はみられなかった。

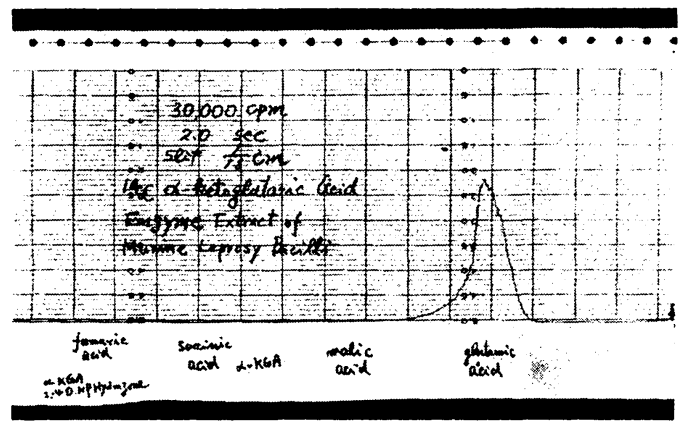

Fig. 4. Radio Active Glumtamic Acid Formation from Radio Active $\alpha$-Ketoglutaric Acid

$0.05 \mathrm{mc}$ of $5^{14} \mathrm{C} \alpha$-ketoglutaric acid, specific activity $9.33 \mathrm{mc} / \mathrm{mM}$ was used as substrate without adding carrier cold $\alpha$-ketoglutarate. $\quad 1.5 \mathrm{~g}$ of lyophylized murine leprosy bacilli (Hawaiian Strain) were ground with glass powder, and suspended to $2 \mathrm{ml}$ of phosphate buffer $\mathrm{M} / 50, \mathrm{pH}$ 7.0. The ground cell suspension was used as enzyme, adding $1 \mathrm{mg}$ of phenazine methosulfate and $5 \mathrm{mg}$ of Difco bacto yeast extract. Total volume $3.4 \mathrm{ml}$ reaction mixtures were incubated for 300 minutes at $37^{\circ} \mathrm{C}$ under aerobic condition occasionally shaking. Paper-chromatography : reaction material was developed with butanol:formic acid:water $=10: 2: 5$ by ascending method,

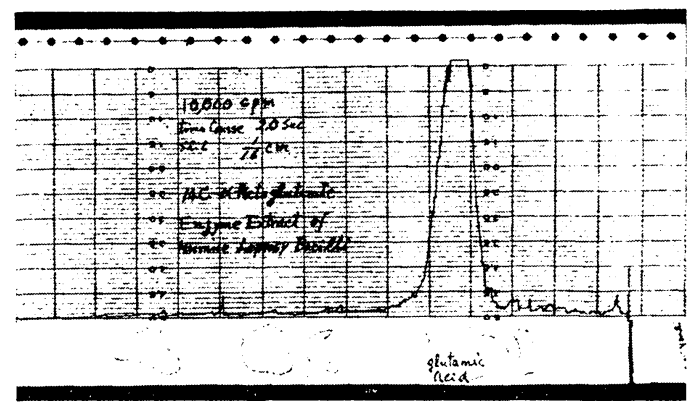

Fig. 5. Radio Active Glutamic Acid Formation from Radio Active $\alpha$-Ketoglutaric Acid

Paper-chromatography: same material, Fig. 4. was developed with water saturated phenol by asceding method.

討 論

鼠癩菌の生菌の内部呼吸をみると，チトクロームがみ られないにもか〉わらず，かなり大量の酸素消費を示 す。また鼠癩生菌の加熱抽出液中にはリンゴ酸の蓄積は みられず,むしろグルタミン酸の蓄積がみられる。これ らのことから，生菌では円滑に代謝系が進行しているの で, 磨砕抽出液にて活性が認められなくても, 鼠癩菌に その酵素活性がないとは言えない。鳥型菌竹尾株におけ るオキザロ醋酸脱炭酸酵素は至適 $\mathrm{pH}$ が 5.0 位でしか あ透析して MgH を加えると活性が増強されると言われ ている ${ }^{15)}$ 。また焦性ブドウ酸， $\alpha$-ケトグルタール酸, イソクエン酸などの酸化的脱炭酸反応には, 複雑な酵素 系が働いているので, 磨砕抽出液では失活する可能性も たかい。鳥型菌竹尾株であ $\alpha$ 的脱炭酸反応はアセトン乾燥菌ではみとめられるが, 磨 哗抽汒液ではみとめられないと言われている15)。TCA 
サイクル系で活性のみとめられなかった酵素活性につい ては，別の代謝系を検討するとともに，鼠癩菌の終末電 子伝達系之関連せしめて研究しなければならない。まだ ての間に不明なととは多々あるが, 初期の目的である鼠 癩菌培養の手がかりと云う点において, 問題は培地に用 いる炭素源にあるのではなく, 終末電子伝達系化あると 云えるであろう。

\section{総括}

1. 鼠癩菌はフマレート・ハイドラテース活性を有 し，フマール酸からリンゴ酸を形成する。

2. 鼠癩菌はコ八ク酸脱水素酵素活性を有し，コハク 酸からフマール酸を形成する。

3. 鼠癩菌はアコニテート・ハイドラテース活性を有 し、シス・アコニット酸およびイソクエン酸から クエン酸を形成する。

4. 鼠瀬菌はサイトレート・ジンテース（縮合酵素） 活性を有し，アセチル CoA とオキザロ醌酸から クエン酸を形成する。しかしアセチル CoA の代 りに焦性ブドウ酸, チアミンピロ燐酸, 助醅素 $\mathrm{I}, \mathrm{CoA}$, リポ酸を用いてもクエン酸の形成はみ られなかった。

5. 鼠癩菌のイソサイトレート・リアーゼ（イソサイ トリテース）活性を検討したが，イソクエン酸か らグリオキジル酸の形成はみられなかった。

6. 鼠癩菌の $\alpha$-ケトグルタール酸脱水素醉素活性を 検討したが， $\alpha$-ケトグルタール酸からコハク酸 の形成は検出することができなかった。

7. 鼠癩菌は $a$-ケトグル酸からグルタミン酸を形成 する。

8. 鼠瀬菌のグルタミン酸脱炭酸酵素活性を検討した

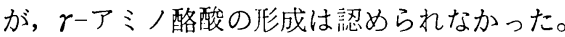

\section{文献}

1) Gray, C.T.: The respiratory metabolism of murine leprosy bacilli. J. Bacteriol. 64, 305313, (1952)

2) Ito, T. and Sonoda, R. : Biochemical studies on the murine leprosy bacillus. II. Respiration and respiration accelerating substances. Biken's J. 1, 157-165, (1958)

3) Mori, T., Kosaka, K. and Ito, T. : Carbohydrate metabolism of the murine leprosy bacillus. I. Studies on the Respiratory enzyme system, especially the diaphorase and malic dehydrogenase activities. Biken's J. 4, 225-233, (1961)

4) Kusaka, T., Yamanouchi, T., Shoji, K., Mori, T., Ito, T. and Sato, R. : Isolation of BCG cell grown in vitro and a comparative study of cytochromes in Mycobacteria grown in vitro and in vivo. La Lepro, 33, 28-37, (1964)

5) Mori, T., Kosaka, K. and Ito., T. : Detection by nile blue staining of tissue contaminants in murine leprosy bacilli preparation. Biken's J. 3, 261-263, (1960)

6) Mori, T., Kosaka, K., Ito, T. and Nishimura, S. : Collection of murine leprosy bacillus. Jap. J. Bact. 16, 808-813, (1961)

7) Natelson, S., J.B. Pincus and J.K. Lugovoy: Microestimation of citric acid, a new colorimetric reaction for pentabromo acetone. J. Biol, Chem. 175, 745-750, (1948)

8) Friedmann, T.E. and G.E. Haugen : Pyruvic acid II, the determination of ketoacids blood and urine. J. Biol. Chem. 147, 415-442, (1943)

9) Singer, T., E. Kearney and V. Massey : Newer knowledge of succinic dehydrogenase. Advance in Enzymology. 18, 76-79, (1957)

10) Korkes, S., A.D. Campillo I.C. Gunsalus and S. Ochoa: Enzymatic synthesis of citric acid IV. pyruvate as acetyl donor. J. Biol. Chem. 193, 721-735, (1951)

11) Asano, A., T. Kaneshiro and A.F. Brodie: Malate-vitamin $\mathrm{K}$ reductase, a phospholipidrequiring enzyme. J. Biol. Chem. 240, 895905, (1965)

12) Krampitz, L. O. and C. H. Werkman: The enzymic decarboxylation of oxaloacetate. Biochem. J. 35, 595-602, (1941)

13) Vennesland, B. and E.A. Evans : The formation of malonic acid from oxaloacetic acid by pig heart preparations. J. Biol. Chem. 156, 783-784, (1944)

14) Ochoa, S. and E.W. Tabori : Biosynthesis of tricarboxylic acid by carbon dioxide fixation II, oxalosuccinic carboxylase. J. Biol. Chem. 174, 123-132, (1948)

15) Yamamura. Y., M. Kusunose, S. Nagai and E, 
Kusunose : Studies on the tricarboxylic acid cycle in Tubercle bacillus, I. some properties of the enzyme systems. J. Biochem. 41, 513-528, (1954)

16) Saz, H.J. and E.P. Hillary: The formation of glyoxylate and succinate from tricarboxylic acids by Pseudomonas aeruginosa. Biochem. J.
62, 563-569, (1965)

17) Shoji, K., T. Mori and K. Ito: Studies on the amino acid metabolism of Mycobacterium Tuberculosis II. $r$-aminobutyric acid- glutamic acid transamination of Mycobacterium avium, strain Takeo. Medical Journal of Osaka University, 8, 607-613, (1958) 